\title{
Heat-treatment reduces anti-nutritional phytochemicals and maintains protein quality in genetically improved hulled soybean flour
}

Ariela Werneck de CARVALHO ${ }^{1}$, Dorina Isabel Gomes NATAL ${ }^{1}$, Cassiano Oliveira da SILVA ${ }^{2}$, Maria Inês de Souza DANTAS ${ }^{1}$, Everaldo Gonçalves de BARROS ${ }^{3}$, Sônia Machado Rocha RIBEIROㄹ, Neuza Maria Brunoro COSTA ${ }^{4}$, Hércia Stampini Duarte MARTINO ${ }^{1 *}$

\begin{abstract}
The soybean is a protein source of high biological value. However, the presence of anti-nutritional factors affects its protein quality and limits the bioavailability of other nutrients. The effect of heat-treatment, $150{ }^{\circ} \mathrm{C}$ for 30 minutes, on hulled and hull-less soybean flour from the cultivar UFVTN 105AP on urease, trypsin inhibitor activity, protein solubility, amino acid profile, and in vivo protein quality was investigated. The treatment reduced the trypsin inhibitor activity and urease, but it did not affect protein solubility. Protein Efficiency Coefficient (PER) values of the flours were similar, and the PER of the hull-less soybean flour did not differ from casein. The Net Protein Ratio (NPR) did not differ between the experimental groups. The True Digestibility (TD) of the flours did not differ, but both were lower in casein and the Protein Digestibility Corrected Amino Acid Score (PDCCAS) was lower than the TD, due to limited valine determined by the chemical score. Therefore, the flours showed reduced anti-nutritional phytochemicals and similar protein quality, and therefore the whole flours can be used as a source of high quality protein.
\end{abstract}

Keywords: amino acids; trypsin inhibitor; protein solubility.

\section{Introduction}

Soybean [Glycine max (L.) Merrill] is an important legume among vegetable foods because it is a source of high-quality digestible proteins (MENDES et al., 2007; ESTEVES et al., 2010). In addition, it contains dietary fiber, minerals, and essential fatty acids (ESTEVES et al., 2010).

Despite its high nutritional value, there are many compounds in the soybean grain that can interfere with protein quality including protease inhibitors, phytic acid, and lipoxygenase enzymes (ESTEVES et al., 2010). The presence of protease inhibitors, Kunitz trypsin inhibitor (KTI), and Browman-Birk, inhibitor of chymotrypsin (BBI), results in a reduction in protein digestibility thus limiting the availability of essential amino acids (MONTEIRO et al., 2004; DIA et al., 2012). Phytic acid can decrease the bioavailability of proteins by binding to peptides and amino acids thereby inhibiting proteolytic enzyme action (DEAK; JOHNSON, 2007). Additionally, lipoxygenases catalyse lipid hydroperoxidation leading to the so-called beany flavor thus limiting the consumption of soybean products (ESTEVES et al., 2010; FELIX; CANNIATTI BRAZACA; MACHADO, 2011).

The soybean hull is considered a source of dietary fiber and iron (MARTINO et al., 2011), but because it contains some anti-nutritional compounds, its use in flour processing, for example, is limited (MACHADO et al., 2008; ESTEVES et al., 2010; SILVA et al., 2010).
To overcome this problem and increase the consumption of whole soybean, different types of heat-treatment have been used in grains to inactivate or reduce the activity of antinutritional compounds (MACHADO et al., 2008; SILVA et al., 2010). Additionally, genetic breeding efforts have been made to develop improved cultivars devoid of seed protease inhibitors and lipoxygenases (BARROS et al., 2008; ESTEVES et al., 2010).

The aim of this study was to evaluate the effect of thermal processing on urease and trypsin inhibitor activity, protein solubility, amino acid profile, and in vivo protein quality in preparations of flours made from hulled and hull-less soybeans from a newly developed soybean cultivar UFVTN 105AP, which has a high protein content and no seed lipoxygenases.

\section{Materials and methods}

\subsection{Preparation of soybean flours}

The cultivar UFVTN 105AP used to prepare the flours is a new cultivar destined for human consumption and developed by the Institute of Biotechnology for Applied Agriculture (BIOAGRO), Federal University of Viçosa (UFV), Viçosa, MG, Brazil. This cultivar is devoid of the three lipoxygenase isoforms (LOX1, LOX2 and LOX3); it presents high protein content $(43.1 \%)$ and has better flavor than conventional cultivars (MARTINO et al., 2011).

${ }^{1}$ Departamento de Nutrição e Saúde - DNS, Universidade Federal de Viçosa - UFV, Campus Universitário, CEP 36570-000, Viçosa, MG, Brazil, e-mail: hercia@ufv.br

${ }^{2}$ Faculdade de Medicina, Universidade Federal de Uberlândia - UFU, Uberlândia, MG, Brazil

${ }_{3}$ Departamento de Biologia Geral, Instituto de Biotecnologia Aplicada à Agropecuária - BIOAGRO, Universidade Federal de Viçosa - UFV, Viçosa, MG, Brasil.

${ }^{4}$ Centro de Ciências Agrárias, Universidade Federal do Espírito Santo - UFES, Alegre, ES, Brazil

${ }^{*}$ Corresponding author 
Four types of flours were prepared: raw hulled soybean flour; raw hull-less soybean flour; treated hulled soybean flour; and treated hull-less soybean flour. From $1 \mathrm{~kg}$ of soybeans, $917 \mathrm{~g}$ of hulled soybean flour and $869 \mathrm{~g}$ of hull-less soybean flour were produced on average for each repetition. The grains were selected, washed, and dried at room temperature. For the preparation of raw hulled soybean flour, the grains were ground using a knife mill (Brabender ${ }^{\oplus}$, Rotary Mill model, Duisburg, Germany) and passed through a 20 mesh sieve $(0.84 \mathrm{~mm})$ (Telastem ${ }^{\circ}$, São Paulo, Brazil) using an electric shaker (W.S. Tyler ${ }^{\circledR}$ model Ro-tap, Cleveland, USA). For the production of raw hull-less soybean flour, the grains were processed using a semi-industrial blender (Profit ${ }^{\circ}$, Catanduva, São Paulo, Brazil) to separate the hull and then crushed. To prepare the treated soybean flours, the grains were subjected to heattreatment at $150{ }^{\circ} \mathrm{C}$ for 30 minutes in a forced air circulation oven (Nova Ética ${ }^{\oplus}$, model 400/6ND, Vargem Grande Paulista, São Paulo, Brazil), cooled and stored in polyethylene bags (ANDRADE et al., 2010). Next, the same procedures described for the preparation of raw soybean flours were followed. All of the flours were prepared in three repetitions.

\subsection{Urease, trypsin inhibitor and protein solubility}

The urease activity was determined by the difference in $\mathrm{pH}$ of the samples, according to the method described by AOCS (AMERICAN..., 1978).

Trypsin inhibitor activity was evaluated in the four soybean flour extracts, according to the method described by Erlanger, Kokowosky and Cohen (1961) with slight modifications. For the preparation of soybean extract, $100 \mathrm{mg}$ of defatted sample and $10 \mathrm{~mL}$ of $0.1 \mathrm{M}$ Tris- $\mathrm{HCl}$ buffer, $\mathrm{pH} 8.2$, were homogenized in an Erlenmmeyer containing $20 \mathrm{mM} \mathrm{CaCl}$ This suspension was agitated for 3 hours and centrifuged for $35.600 \mathrm{~g}$ for 20 minutes. In a test tube, $450 \mu \mathrm{L}$ of buffer and $50 \mu \mathrm{L}$ of trypsin solution and $100 \mathrm{~mL}$ of soybean extract were added, homogenized and left at room temperature for 5 minutes. Next, $500 \mu \mathrm{L}$ of the homogenate were removed and transferred to a new test tube containing $500 \mu \mathrm{L}$ of buffer and $500 \mu \mathrm{L}$ of the $\mathrm{D}, \mathrm{L}-\mathrm{BApNA}$ solution. The solution was agitated and left at room temperature for 5 minutes; the reaction was stopped by the addition of $300 \mu \mathrm{L}$ of $60 \%$ acetic acid. Absorbance of the solution was determined at $410 \mathrm{~nm}$ using a spectrophotometer (PG Instrumental ${ }^{\circledR}$ model $\mathrm{T} 70+\mathrm{UV} /$ visible spectrometer, Leics, UK), and the results were converted in $\mathrm{mg}$ of inhibited trypsin per gram of total protein in the sample.

Protein solubility determination was based on nitrogen solubility in a $0.2 \%$ potassium hydroxide $(\mathrm{KOH})$ solution, and the results were expressed as the percentage of soluble nitrogen in relation to the total nitrogen (BRASIL, 1991).

\subsection{Amino acid profile}

Heat-treated hulled and hull-less soybean flours were hydrolyzed in hydrochloric acid for 24 hours at $109-111^{\circ} \mathrm{C}$ and again with $4 \mathrm{M}$ lithium hydroxide to quantify tryptophan. The samples were filtered and the aliquots were injected into cation-exchange columns (short column for basic amino acids and tryptophan, long column for acid and neutral amino acids) and eluted by $\mathrm{pH}$ difference and ionic force (short column $\mathrm{pH}$ 5.28 long column pH 3.25 and later 4.25). Amino acids were eluted in a cation-exchange column (Resin: PC 6A Amino Acid Analysis Resin Pierce), reacted with ninhydrin, and quantified by spectrophotometry (PG Instrumental ${ }^{\circ}$, model T70 + UV/ visible spectrophotometer, Leics, United Kingdom) at $440 \mathrm{~nm}$ for proline and $570 \mathrm{~nm}$ for the other amino acids (SPACKMAN; STEIN; MOORE, 1958).

\subsection{Experimental diets}

Four experimental diets were prepared: a casein based control diet, a basal diet (nitrogen-free), and the other two with heat-treated hulled and hull-less soybean flours (Table 1).

The composition of the experimental diets was based on the AIN-93G diet (REEVES; NIELSEN; FAHEY JÚNIOR, 1993) and modified to provide $9.5 \%$ protein. The proximate composition of the soybean flours, determined by methods recommended by the AOAC (ASSOCIATION..., 1997), was used for the calculations of the experimental diets so that they were isoproteic. The protein content of the diets was determined in triplicate by the semimicro Kjeldahl method (ASSOCIATION..., 1997).

\subsection{Biological assay}

Twenty four male Wistar rats (Rattus norvegicus, variety albinus, class Rodentia), weaned at 23 days old and weighting $56 \mathrm{~g}$, obtained from the Central Biotery, Federal University of Viçosa, Minas Gerais, Brazil were used in this experiment. The animals were systematically divided into groups of six rats, so that the mean weight of each group did not differ from the others by more than $2.2 \mathrm{~g}$, following the recommendations of the AOAC (ASSOCIATION..., 1997). Next, the animals were kept in individual stainless steel cages in a room with controlled temperature $\left(22 \pm 3{ }^{\circ} \mathrm{C}\right)$ and a 12 hour photoperiod. The rats received water and food ad libitum during the 14 day experimental period. Euthanasia of the animals was performed

Table 1. Composition of experimental diets $\left(\mathrm{g} \cdot 100 \mathrm{~g}^{-1}\right)$.

\begin{tabular}{|c|c|c|c|c|}
\hline Ingredients & NF & Casein & THSF & THLSF \\
\hline Casein (Rhoster $\left.{ }^{\oplus}\right)$ & - & 11.5 & - & - \\
\hline Treated hulled soybean flour & - & - & 22.1 & - \\
\hline Treated hull-less soybean flour & - & - & - & 20.8 \\
\hline Dextrinated starch (Amidex $\left.{ }^{\star}\right)$ & 13.2 & 13.2 & 13.2 & 13.2 \\
\hline Sucrose $\left(\right.$ União $\left.^{\circledR}\right)$ & 10.0 & 10.0 & 10.0 & 10.0 \\
\hline Soybean oil (Soya $\left.{ }^{\star}\right)$ & 7.0 & 7.0 & 2.9 & 3.1 \\
\hline Microfine cellulose $\left(\right.$ Comprecel $\left.^{\circledR}\right)$ & 5.0 & 5.0 & 1.9 & 3.5 \\
\hline Mix mineral (Rhoster ${ }^{\varpi}$ & 3.5 & 3.5 & 3.5 & 3.5 \\
\hline Mix vitamin (Rhoster $\left.{ }^{\circledast}\right)$ & 1.0 & 1.0 & 1.0 & 1.0 \\
\hline Choline bitartrate (Rhoster $\left.{ }^{\star}\right)$ & 0.3 & 0.3 & 0.3 & 0.3 \\
\hline L-cistin $\left(\right.$ Rhoster $\left.^{\circledast}\right)$ & 0.3 & 0.3 & 0.3 & 0.3 \\
\hline Corn starch (Pink Alimentos ${ }^{\circledR}$ ) & 59.8 & 48.3 & 44.8 & 44.4 \\
\hline Caloric density (Kcal.g ${ }^{-1}$ ) & 3.6 & 3.7 & 3.1 & 3.6 \\
\hline
\end{tabular}

NF - Nitrogen free; THSF - Treated hulled soybean flour; THLSF - Treated hull-less soybean flour. 
immediately after the end of experimentation by asphyxiation in an environment containing $\mathrm{CO}_{2}$.

Weight gain and food consumption were monitored weekly. The Food Efficiency Ratio (FER) was calculated as the ratio between the weight gain of the animal (g) and diet consumption (g). The Protein Efficiency Coefficient (PER) was determined considering the weight gain of the test group in relation to the protein intake of the test group (HEGSTED, 1977). The Net Protein Ratio (NPR) was determined on the $14^{\text {th }}$ experimental day considering the weight gain of the test group plus the weight loss of the nitrogen-free group in relation to protein intake of the test group, according to the method of Bender and Doell (1957).

For the True Digestibility (TD) analysis, on the $8^{\text {th }}$ experimental day, the animals received diets marked with 200 mg indigo carmine per $100 \mathrm{~g}$ of diet. The marked feces were collected on the $9^{\text {th }}$ experimental day; all feces were collected on the $10^{\text {th }}$ and $11^{\text {th }}$ days, and only the non-marked feces were collected on the $12^{\text {th }}$ day. The feces collected within this period were packed in individual recepticals, kept under refrigeration, and dried in a forced air circulating oven (Marconi ${ }^{\oplus}$ model MA 035, Piracicaba, Brazil) at $105^{\circ} \mathrm{C}$ for 24 hours. They were then cooled, weighed, and ground using a mini food processor (Arno ${ }^{\circledR}$ model PRC, São Paulo, Brazil) to determine, in triplicate, the nitrogen content by the Kjeldahl method (ASSOCIATION..., 1997). The nitrogen content of the feces from the experimental groups was used to calculate the True Digestibility (FOOD..., 1991).

The procedures adopted in the biological assay met the scientific and didactic practice requirements for animal vivisection and was approved by the Ethics Committee on Animal Experimentation (CETEA), Federal University of Minas Gerais (UFMG), protocol number 252/2008.

\subsection{Protein Digestibility Corrected Amino Acids Score (PDCAAS)}

The amino acid score was determined by the ratio between the amino acid profile of the soybean flours and the reference standard for amino acids (FOOD..., 2007). The PDCAAS was calculated by multiplying the lowest essential amino acid score by the true protein digestibility; PDCAAS > 100 was considered good quality (HENLEY; KUSTER, 1994).

\subsection{Statistical analysis}

The results were assessed by ANOVA, according to the post hoc test, with Duncan's test at 5\% probability and are expressed as the mean \pm standard deviation of tree repetitions for the chemical characterization and the mean \pm standard deviation of six repetitions for the biological assay. The statistical analyses were performed using the Statistical Analysis System (SAS), version 9.0 (2002), licensed for use by the Federal University of Viçosa.

\section{Results and discussion}

\subsection{Urease, trypsin inhibitor, and protein solubility}

The urease activity of the raw soybean flours was higher ( $p<0.05)$ than that of the treated flours, but there was no difference between the hulled and hull-less soybean flours ( $p>$ 0.05) (Table 2). Heat-treated flours reached values of $\mathrm{pH}$ units within the recommended classification (0.05-0.30), while the raw flours showed undesirable indices, greater than 0.30 (BRITO et al., 2006). Thus, heat-treatment in the oven was adequate to reduce urease activity, which was a good indicator of trypsin inhibition (WIRIYAUMPAIWONG; SOPONRONNARIT; PRACHAYAWARAKORN, 2004; MACHADO et al., 2008).

The heat-treatment used in this study was sufficient to completely inactivate the trypsin inhibitor (Table 2), demonstrating the efficiency of heat-treatment in an oven at $150^{\circ} \mathrm{C}$ for 30 minutes. Similar results were found by Mendes et al. (2007) and Machado et al. (2008), who reported inactivation of inhibitors to desirable levels after autoclaving soybeans at $120^{\circ} \mathrm{C}$ for 18 minutes and $121^{\circ} \mathrm{C}$ for 10 minutes, respectively.

Moreover, a previous study in our laboratory showed that oven heat-treatment at $150{ }^{\circ} \mathrm{C}$ for 30 minutes was also sufficient to decrease the concentration of myo-inositol hexaphosphate and pentaphosphate present in soybean flours (MARTINO et al., 2011) and which can affect protein quality (KUMAR et al., 2010).

The protein solubility of treated and raw hulled soybean flours were higher than that of hull-less soybean flours $(p<0.05)$. Despite the evidence that the hull-less soybean flour had lower protein solubility than the hulled flour, this value was within the adequate range (BRITO et al., 2006). Additionally, heat-treatment increased $(\mathrm{p}<0.05)$ the solubility of protein for hull-less soybean flour. Therefore, the heat-treatment of $150{ }^{\circ} \mathrm{C}$ for 30 minutes was efficient to inactivate anti-nutrients and maintain the soybean protein quality.

\subsection{Protein quality in vivo}

Weight gain and food consumption did not differ between the test groups $(p>0.05)$, but were smaller in casein $(p<0.05)$

Table 2. Inhibited trypsin, urease activity, and protein solubility of raw and treated hulled and hull-less soybean flour at $150{ }^{\circ} \mathrm{C}$ for 30 minutes.

\begin{tabular}{lcccc}
\hline & RHSF & RHLSF & THSF & THLSF \\
\hline $\begin{array}{l}\text { Inhibited tripsin } \\
\text { (mg.g }{ }^{-1} \text { of protein) }\end{array}$ & $73^{\mathrm{a}} \pm 0.32$ & $71^{\mathrm{b}} \pm 0.00$ & $0.00^{\mathrm{c}} \pm 0.00$ & $0.00^{\mathrm{c}} \pm 0.00$ \\
$\begin{array}{l}\text { Urease activity } \\
\text { (pH difference) }\end{array}$ & $0.82^{\mathrm{b}} \pm 0.05$ & $0,91^{\mathrm{a}} \pm 0.02$ & $0.03^{\mathrm{c}} \pm 0.02$ & $0.03^{\mathrm{c}} \pm 0.01$ \\
Protein solubility (\%) & $93^{\mathrm{a}} \pm 1.43$ & $81^{\mathrm{c}} \pm 0.13$ & $94^{\mathrm{a}} \pm 2.00$ & $86^{\mathrm{b}} \pm 2.08$ \\
\hline
\end{tabular}

Means followed by same letter in the same row do not differ by the Duncan's test at 5\% probability. RHSF - Raw hulled soybean flour; RHLSF Raw hull-less soybean flour; THSF - Treated hulled soybean flour; THLSF - Treated hull-less soybean flour. 
(Table 3) although FER did not differ among the experimental groups $(p>0.05)$. The diets tested were able to promote the same weight gain per gram of diet consumed compared to the casein diet.

The PER value of the group fed hulled soybean flour was lower than the others $(\mathrm{p}<0.05)$. However, hulled soybean flour can also be considered efficient for promoting good growth rate since protein sources with PER above 2.0 are considered good or of high quality (FRIEDMAN, 1996). The difference between the PER values of the hulled and hull-less soybean flours may be due to the dietary fiber complexation with protein, which can also limit the enzymatic hydrolysis and the use of protein.
There was no significant difference $(p>0.05)$ in the NPR value for the experimental groups, and the difference of up to 14.2\% between PER and NPR confirms the soybean protein quality (Table 3). The results confirm that the increase in protein content of the new cultivar UFVTN 105AP was effective to improve the protein quality indices.

Protein intake of the group fed hull-less soybean flour was lower than that of the other groups $(p<0.05)$ (Table 3$)$ although the food intake was the same for test groups. The fecal weight did not differ $(\mathrm{p}>0.05)$ among the experimental groups. The group fed hulled soybean flour had the highest nitrogen excretion. Hulled soybean flour has a more complex food matrix which can affect enzyme activity increasing nitrogen

Table 3. Means and standard deviation of Weight gain, Food Intake, Food Efficiency Ratio (FER), Protein Intake, Protein Efficiency Ratio (PER), Protein Efficiency Ratio Relative (PERR), Net Protein Ratio (NPR) and Net Protein Ratio Relative (NPRR) of the experimental groups.

\begin{tabular}{|c|c|c|c|c|c|c|c|c|}
\hline & $\begin{array}{l}\text { Weight gain } \\
\text { (g) }\end{array}$ & $\begin{array}{l}\text { Food intake } \\
(\mathrm{g})\end{array}$ & FER & $\begin{array}{c}\text { Protein intake } \\
(\mathrm{g})\end{array}$ & PER & PERR & NPR & NPRR \\
\hline Casein & $52^{\mathrm{a}} \pm 8.9$ & $167^{a} \pm 15$ & $0.31^{\mathrm{a}} \pm 0.04$ & $36^{\mathrm{a}} \pm 3.9$ & $3.2^{\mathrm{a}} \pm 0.40$ & 100 & $4.0^{\mathrm{a}} \pm 0.38$ & 100 \\
\hline THSF & $31^{\mathrm{b}} \pm 9.1$ & $122^{\mathrm{b}} \pm 30$ & $0.25^{\mathrm{a}} \pm 0.03$ & $29^{\mathrm{ab}} \pm 7.7$ & $2.5^{\mathrm{b}} \pm 0.29$ & 77 & $3.6^{\mathrm{a}} \pm 0.25$ & 89 \\
\hline THLSF & $30^{\mathrm{b}} \pm 9.8$ & $105^{\mathrm{b}} \pm 19$ & $0.27^{\mathrm{a}} \pm 0.06$ & $24^{\mathrm{b}} \pm 5.9$ & $2.7^{\mathrm{ab}} \pm 0.59$ & 85 & $4.0^{\mathrm{a}} \pm 0.45$ & 99 \\
\hline
\end{tabular}

Means followed by same letter in the same column do not differ by the Duncan test at 5\% probability. THSF - Treated soybean hulled flour; THLSF - Treated hull-less soybean flour.

Table 4. Fecal weight, Nitrogen Excreted and True Digestibility (TD) of experimental groups.

\begin{tabular}{lcccc}
\hline & Fecal weight $(\mathrm{g})$ & Nitrogen Excreted & TD (\%) & TDR \\
\hline Casein & $2.2^{\mathrm{a}} \pm 0.34$ & $0.04^{\mathrm{b}} \pm 0.01$ & $94^{\mathrm{a}} \pm 0.89$ & 100 \\
THSF & $1.9^{\mathrm{a}} \pm 0.56$ & $0.08^{\mathrm{a}} \pm 0.03$ & $85^{\mathrm{b}} \pm 2.5$ & 90 \\
THLSF & $1.8^{\mathrm{a}} \pm 0.43$ & $0.06^{\mathrm{b}} \pm 0.01$ & $87^{\mathrm{b}} \pm 2.6$ & 92 \\
\hline
\end{tabular}

Means followed by same letter in the same column do not differ by the Duncan test at 5\% probability. THSF - Treated hulled soybean flour; THLSF - Treated hull-less soybean flour.

Table 5. Amino acid profile, chemical score (score AA), and PDCAAS according to the standard FAO/WHO (FOOD..., 2007) of treated hulled and hull-less soybean flours.

\begin{tabular}{|c|c|c|c|c|c|c|c|}
\hline \multirow{2}{*}{ Amino acids } & \multicolumn{2}{|c|}{ mg.g $g^{-1}$ protein } & \multirow{2}{*}{ Standard FAO/WHO } & \multicolumn{2}{|c|}{ Score AA } & \multicolumn{2}{|c|}{ PDCAAS } \\
\hline & THSF & THLSF & & THSF & THLSF & THSF & THLSF \\
\hline \multicolumn{8}{|l|}{ Essential } \\
\hline Phenylalanine + Tyrosine & 88 & 91 & 46 & 1.9 & 2.0 & - & - \\
\hline Histidine & 28 & 25 & 18 & 1.6 & 1.4 & - & - \\
\hline Isoleucine & 33 & 37 & 31 & 1.1 & 1.2 & - & - \\
\hline Leucine & 76 & 80 & 63 & 1.2 & 1.3 & - & - \\
\hline Lysine & 59 & 54 & 52 & 1.1 & 1.1 & - & - \\
\hline Methionine + Cystine & 27 & 26 & 26 & 1.0 & 1.0 & - & - \\
\hline Threonine & 41 & 42 & 27 & 1.5 & 1.6 & - & - \\
\hline Tryptophan & 19 & 16 & 7.4 & 2.6 & 2.2 & - & - \\
\hline Valine & 32 & 35 & 42 & 0.77 & 0.83 & 65 & 72 \\
\hline \multicolumn{8}{|l|}{ Non-essential } \\
\hline Arginine & 77 & 68 & - & - & - & - & - \\
\hline Alanine & 48 & 46 & - & - & - & - & - \\
\hline Aspartic Acid & 128 & 134 & - & - & - & - & - \\
\hline Glutamic Acid & 199 & 200 & - & - & - & - & - \\
\hline Glycine & 49 & 45 & - & - & - & - & - \\
\hline Proline & 59 & 63 & - & - & - & - & - \\
\hline Serine & 55 & 55 & - & - & - & - & - \\
\hline
\end{tabular}

Score de $\mathrm{AA}=\mathrm{mg}$ of aa/g protein TSHF or THSF $=\mathrm{mg}$ of aa/g protein standard FAO/WHO; PDCAAS: $1^{\text {st }}$ amino acid limited (column IV) $\times$ true digestibility of experiment with rats;

True Digestibility: THSF $=85$; $($ TDHSF $)=87$ THSF - Treated hulled soybean flour; THLSF - Treated hull-less soybean flour. 
excretion. This fact did not affect the TD since both hulled and hull-less flours showed similar results $(p>0.05)$ (Table 4). In addition, the TDR of the soybean flours prepared was higher than $80 \%$, which indicates high protein digestibility in the new cultivar (FOOD..., 2007). Thus, the use of the hulled soybean flour did not reduce protein quality maintaining the soybean inherent benefits.

\subsection{Amino acid profile and Protein Digestibility Corrected Amino Acids Score (PDCAAS)}

The soybean flours showed adequate essential amino acid profile, except for valine, with PDCAAS values of $65 \%$ and $72 \%$ for the heat-treated hulled and hull-less soybean flour, respectively (Table 5).

The amino acid profile of the soybean flours indicated that the flours made from the new cultivar overcame the limitation in sulfur amino acids normally found in legumes (UNITED..., 2012). The amino acid composition of the soybean cultivar UFVTN 105AP was better than that of its progenitor UFVTN 105 with normal protein content, which showed limitations in methionine, cystine, lysine, histidine, threonine, and valine by the standard FAO (FOOD..., 2007; MORAES et al., 2006). The development of a cultivar with high protein content was essential to improve the soybean amino acid balance and promote greater nutritional benefits to consumers since the cultivar UFVTN $105 \mathrm{AP}$ was limited only in valine content, and the conventional cultivar contained limited amounts of multiple essential amino acids (UNITED..., 2012; PIRES et al., 2006; FRIKHA et al., 2012). Moreover, by comparing the patterns obtained with those of FAO (FOOD..., 1985) and IOM (INSTITUTE..., 2002), the flours showed no limitation in essential amino acids.

\section{Conclusion}

Hulled and hull-less soybean flours from genetically improved soybeans submitted to heat-treatment at $150{ }^{\circ} \mathrm{C}$ for 30 minutes had reduced anti-nutrient phytochemical activity and similar levels of quality protein indicating that this legume can be used as a high quality protein source.

\section{Acknowledgements}

The authors are grateful for the financial support provided by FAPEMIG, FINEP and CAPES - Brazil.

\section{References}

ANDRADE, G. F. et al. Tratamento térmico adequado proporciona melhoria da qualidade nutricional de farinhas de soja elaboradas a partir de novos cultivares destinados à alimentação humana. Revista do Instituto Adolfo Lutz, v. 69, n. 4, 2010.

ASSOCIATION OF OFFICIAL ANALYTICAL CHEMISTS - AOAC. Official methods of analysis of AOAC International. 16th ed. Gaitheersburg: AOAC, 1997.

AMERICAN OIL CHEMISTS' SOCIETY - AOCS. Tentative method Ba 9-58 - Urease activity. In: SMITH, A. K.; CIRCLE, S. J. (Eds.). Soybeans: Chemistry and technology. Westport: AVI, 1978. p. $454-455$.
BARROS, J. G. A. et al. Efeito do inibidor de protease Kunitz sobre níveis de lipoxigenases em semente de soja. Ciência e Agrotecnologia, v. 32, p. 1126-1132, 2008. http://dx.doi.org/10.1590/S141370542008000400014

BENDER, A. E.; DOELL, B. H. Note on the determination of net protein utilization by carcass analysis. British Journal of Nutrition, v. 11, p. 138-143, 1957. PMid:13426454. http://dx.doi.org/10.1079/ BJN19570028

BRASIL. Portaria n ${ }^{\circ} 108$, de 04 setembro de 1991. Estabelece os Métodos Analíticos para Controle de Alimentos para uso Animal. Diário Oficial da República Federativa do Brasil, Brasília, DF, set. 1991. Seção 1, p. 19813-19842.

BRITO, C. O. et al. Adição de complexo multienzimático em dietas à base de soja extrusada e desempenho de pintos de corte. Revista Brasileira de Zootecnia, v. 35, n. 2, p. 457-461, 2006. http://dx.doi. org/10.1590/S1516-35982006000200017

DEAK, N. A.; JOHNSON, L. A. Fate of phytic acid in producing soy protein ingredients. Journal of the American Oil Chemists' Society, v. 84, n. 4, p. 369-376, 2007.

DIA, V. P. et al. Bowman-Birk and Kunitz Protease Inhibitors among Antinutrients and Bioactives Modified by Germination and Hydrolysis in Brazilian Soybean Cultivar BRS 133. Journal of Agriculture and Food Chemistry, v. 60, p. 7886-7894, 2012. PMid:22800092. http://dx.doi.org/10.1021/jf301926w

ESTEVES, E. A. et al. Chemical composition of a soybean cultivar lacking lipoxygenases (LOX2 and LOX3). Food Chemistry, v. 122 , n. 1, p. $238-242,2010$. http://dx.doi.org/10.1016/j. foodchem.2010.02.069

ERLANGER, B. F.; KOKOWOSKY, N.; COHEN, W. The preparation and properties of two new chromogenic substrates of trypsin. Archives of Biochemistry and Biophysics, v. 95, n. 2, p. 271-278, 1961. http:// dx.doi.org/10.1016/0003-9861(61)90145-X

FELIX, M. A.; CANNIATTI BRAZACA, S. G.; MACHADO, F. M. V. F. Análise sensorial dos grãos de soja (Glycine max (L.) Merril) tostados por diferentes tratamentos. Ciência e Tecnologia de Alimentos, v. 31, n. 1, p. 56-64, 2011. http://dx.doi.org/10.1590/ S0101-20612011000100007

FOOD AND AGRICULTURE ORGANIZATION OF THE UNITED NATIONS - FAO. Energy and Protein Requeriments. Geneva: FAO/WHO, 1985.

FOOD AND AGRICULTURE ORGANIZATION OF THE UNITED NATIONS - FAO. Protein quality evaluation. Rome: FAO/ WHO, 1991. $66 \mathrm{p}$.

FOOD AND AGRICULTURE ORGANIZATION OF THE UNITED NATIONS - FAO. Protein quality evaluation. Rome: FAO/ WHO, 2007. $66 \mathrm{p}$.

FRIEDMAN, M. Nutritional value of proteins from different food sources. A review. Journal of Agriculture and Food Chemistry, v. 44, p. 6-29, 1996. http://dx.doi.org/10.1021/jf9400167

FRIKHA, M. et al. Correlation between ileal digestibility of amino acids and chemical composition of soybean meals in broilers at 21 days of age. Animal Feed Science and Technology, v. 178, p. 103-114, 2012. http://dx.doi.org/10.1016/j.anifeedsci.2012.09.002

HEGSTED, D. M. Protein quality and its determination. In: WHITAKER, J. R.; TANNENBAUUM, S. R. (Eds.). Food Proteins. Westport: AVI Publishing, 1977. p. 347-362.

HENLEY, E. C.; KUSTER, J. M. Protein quality evaluation by protein digestibility corrected amino acid scoring. Food Technology, v. 4, p. 74-77, 1994. 
INSTITUTE OF MEDICINE - IOM. The Dietary Reference Intakes: Energy, Carbohydrate, Fiber, Fat, Fatty Acids, Cholesterol, Protein, and Amino Acids. Washington: Institute of Medicine of the Nacional Academy Press, 2002.

KUMAR, V. et al. Dietary roles of phytate and phytase in human nutrition: A review. Food Chemistry, v. 120, p. 945-959, 2010. http://dx.doi.org/10.1016/j.foodchem.2009.11.052

MACHADO, F. P. P. et al. Effects of heating on protein quality of soybean flour devoid of Kunitz inhibitor and lectin. Food Chemistry, v. 107, n. 2, p. 649-655, 2008. http://dx.doi.org/10.1016/j. foodchem.2007.08.061

MARTINO, H. S. D. et al. The soybean hull flour of heat-treated grains does not affect iron bioavailability in rats. Archivos Latinoamericanos de Nutrición, v. 61, n. 2, p. 135-142, 2011. PMid:22308939.

MENDES, F. Q. et al. Digestibilidade proteica e caracterização bromatológica de linhagens de soja com ausência ou presença do inibidor de tripsina Kunitz e das isozimas lipoxigenases. Journal of Biosciences, v. 23, p. 14-21, 2007.

MONTEIRO, M. R. P. et al. Qualidade proteica de linhagens de soja com ausência do Inibidor de Tripsina Kunitz e das isoenzimas Lipoxigenases. Revista de Nutrição, v. 17, n. 2, p. 195-205, 2004. http://dx.doi.org/10.1590/S1415-52732004000200006

MORAES, R. M. A. et al. Caracterização bioquímica de linhagens de soja com alto teor de proteína. Pesquisa Agropecuária
Brasileira, v. 41, p. 725-729, 2006. http://dx.doi.org/10.1590/S0100204X2006000500002

PIRES, C. V. et al. Qualidade nutricional e escore químico de aminoácidos de diferentes fontes protéicas. Ciência e Tecnologia de Alimentos, v. 26, n. 1, p. 179-187, 2006. http://dx.doi.org/10.1590/ S0101-20612006000100029

REEVES, P. G.; NIELSEN, F. H.; FAHEY JÚNIOR, G. C. AIN-93 purified diets for laboratory rodents: final report of the american institute of nutrition ad hoc writing committee on the reformulation of the AIN-76A rodent diet. Journal of Nutrition, v. 123, p. 1939-1951, 1993. PMid:8229312.

SILVA, O. C. et al. Influência do processamento na qualidade protéica de novos cultivares de soja destinados à alimentação humana. Revista de Nutrição, v. 23, n. 3, 2010.

SPACKMAN, D. H.; STEIN, W. H.; MOORE, S. Automatic recording apparatus for use in the chromatography of amino acids. Analytical Chemistry, v. 30, n. 7, p. 1190-1206, 1958. http://dx.doi.org/10.1021/ ac60139a006

UNITED STATES DEPARTMENT OF AGRICULTURE - USDA. National Nutrient Database for Standard Reference. Disponível em: <http://www.ars.usda.gov/ba/bhnrc/ndl>. Acesso em: 28 nov. 2012.

WIRIYAUMPAIWONG, S.; SOPONRONNARIT, S.; PRACHAYAWARAKORN, S. Comparative study of heating processes for full-fat soybeans. Journal of Food Engineering, v. 65, p. 371-382, 2004. http://dx.doi.org/10.1016/j.jfoodeng.2004.01.036 